\title{
Investigation of Hepatitis Functioning through Bilurbin at Blood Donors with HBV and HCV Positive
}

\section{Kabengele Arlette Ndaya, A. Mbaz Ruth Kamb, Mulongo Pauline Kalenga, Ilunga Clarisse Manji, Kasongo Narcisse Mwinkeu}

Higher Institute of Medical Techniques of Lubumbashi, Lubumbashi, R. D. Congo

Email:narcissemk@yahoo.fr,ruthkamb09@gmail,comarlettendaya25@gmail.com

How to cite this paper: Ndaya, K.A., Kamb, A.M.R., Kalenga, M.P., Manji, I.C. and Mwinkeu, K.N. (2017) Investigation of Hepatitis Functioning through Bilurbin at Blood Donors with HBV and HCV Positive. Open Access Library Journal, 4: e4166. https://doi.org/10.4236/oalib.1104166

Received: November 17, 2017 Accepted: December 17, 2017 Published: December 20, 2017

Copyright $\odot 2017$ by authors and Open Access Library Inc.

This work is licensed under the Creative Commons Attribution International License (CC BY 4.0).

http://creativecommons.org/licenses/by/4.0/

\begin{abstract}
The analysis of the liver functioning through bilurbin dosage has been up on fifty blood donors. The reactive bandages have been used to seek bilurbines in the urines of those patients considered as carriers with HBV and HCV. After analysis, this descriptive study has shown that out of 31 cases found at men more than 25 years old, 27 cases whose livers don't function present a hyper degree of bilurbine when there is hepatitis. The doorstep of $3.9 \mu \mathrm{mol} / \mathrm{L}$ hold $65.2 \%$ of hepatitis B and hepatitis C. Whereas at the doorstep of $1.5 \mu \mathrm{mol} / \mathrm{L}$ and $7.8 \mu \mathrm{mol} / \mathrm{L}$, the $\mathrm{HBV}$ has got respectively $8.7 \%$ and $26.1 \%$ of cases; and HCV has also got $33.3 \%$ and $26.7 \%$ of cases.
\end{abstract}

\section{Subject Areas}

Biochemistry, Public Health

\section{Keywords}

Investigation, Hepatitis Functioning, Bilurbin, Blood Donors, HBV/HCV Positive

\section{Introduction}

By definition, hepatitis is an inflammation of the liver and it constitutes a big problem of the public health due to several sources. Generally, it is due to the virus, but it is particularly due to one of the viruses of hepatitis which are A, B, C, D, E.

After a long fight against virus, these immune system produce inflammation because of immunitary defence of the virus. This fight leads to trouble (pertuba- 
tion) of liver functioning [1]. The functioning of liver may be explored by bile pigment of which the major one is bilurbine (which is produced at $300 \mathrm{mg}$ a day by a man). The plasma is accumulated with bilurbines that are again absorbed and secreted by the liver, so the kidney leads to icterus [2].

The purpose of this work is to explore, examine the liver function by looking for the bile pigment in the urin of blood donors whose HBV and HCV tests are positives.

Thus, the result that will be obtained will lastly contribute in taking care of those patients suffering from hepatitis discovered at blood donors.

\section{Method and Material}

Among blood check up transfusion required, we do have the detection of B and $\mathrm{C}$ hepatits. For those patients having antibodies against antigens of hepatitis, sample of urine has been required. Whenever the result seems to be positive, we will be searching bile pigments not in the blood but in the urine of either those antigens having $\mathrm{B}$ hepatitis or those having $\mathrm{C}$ hepatitis.

Our researches took place at Jason Sendwe Regional Hospital of Lubumbashi from February to June 2016. Among fifty blood donors considered as a sample, thirty-eight positive cases after a test have been listed. Moreover twenty three blood donors were positive with $\mathrm{B}$ hepatitis and fifteen also positive with $\mathrm{C}$ hepatitis. No case was positive with both hepatitis at the same time. The thirty-eight cases helped as sample with their urines for the biluribin dosage.

After having obtained the authorization of the ethics committee, we conducted this descriptive study. The technique of the reactive bandages has been used and a checkup has also been done directly in urine of positive donors with $\mathrm{HBV}$ and $\mathrm{HCV}$.

After filling a flask at one quarter with urines, a reactive bandage was dived. First this reactive bandage has been observed one minute, than we started reading thanks to the different colors observed referring to the parameters found on the scale review. And lastly, it led to the following results [3]:

- No turn of color: negative outcome

- Coloration turning white yellow: positive (+) at least $1.5 \mu \mathrm{mol} / \mathrm{L}$

- Coloration turning to yellow: positive $(++)$ corresponding to $3.95 \mu \mathrm{mol} / \mathrm{L}$

- Coloration turning to orange: positive $(+++)$ corresponding to $7.85 \mu \mathrm{mol} / \mathrm{L}$

\section{Results}

The detection of hepatitis that has been done at blood donors has shown that $76 \%$ of cases were positive, $46 \%$ with $\mathrm{HB}$ antigene and $30 \%$ with $\mathrm{HC}$ antigene. The other $24 \%$ of remained cases didn't have either hepatitis B or C. The following researches were concerning only on 23 positive patients, or $76 \%$ of cases (Table 1).

Those samples with bile pigments, the doorstep of $3.9 \mu \mathrm{mol} / \mathrm{L}$ corresponding to $(++)$ on the reactive bandages has held more cases at least $65.2 \%$ of $\mathrm{HBV}$ and $40 \%$ of HCV. At the doorstep of $1.5 \mu \mathrm{mol} / \mathrm{L}$ and $7.8 \mu \mathrm{mol} / \mathrm{L}$; Hepatitis B has got 
Table 1. Adjustment of HBV and HCV positive at 50 blood donors.

\begin{tabular}{|c|c|c|c|}
\hline \multicolumn{2}{|c|}{ Antigene results } & Size & Percentage \\
\hline \multicolumn{2}{|c|}{ Negative } & 12 & 24 \\
\hline \multirow[t]{2}{*}{ Positive } & $\mathrm{HBV}$ & 23 & 46 \\
\hline & $\mathrm{HCV}$ & 15 & 30 \\
\hline \multicolumn{2}{|c|}{ Total } & 50 & 100 \\
\hline
\end{tabular}

respectively $8.7 \%$ and $26.1 \%$ of cases and Hepatitis C has also got $33.3 \%$ and $26.7 \%$ of cases (Table 2 ).

Referring to the outcome of this chart III, we have noticed that the patient male sex with HBV and HCV positive regarding to the respective outcome of $86.9 \%$ and $73.3 \%$ against $13.04 \%$ and $26.7 \%$ were dominant to patient female sex (Table 3).

Referring to the age, all the two tests have led to the neighbouring outcome. Patients, more than 25 years old, have been numerous: $69.5 \%$ in the case of hepatitis B and 73\% in the other case hepatitis C (Table 4).

\section{Discussion}

Blood transfusion is a safety problem. In Africa, the results of paraclinical examinations seem to be the problem of transfusion safety with a residual risk that is almost nil [4].

In this study, we are interested in the antigens of the hepatitis $B$ and $C$ viruses. These diseases constitute a real public health problem [5]. In general, urine contains bile pigments including bilurbin and urobilinogen [6]. Bilurbin, interest of the present study, is found in urine at $2 \mathrm{mg} / \mathrm{dl}$ [7]. Hepatic assessment demonstrates the various functions of the liver [6] and urine provides valuable information for this purpose [8].

In our study, the detection of hepatitis that has been done at blood donors has demonstrated that $46 \%$ of cases had hepatits B antogenes and $30 \%$ of other cases had Hepatitis C antigenes. However, 24\% of donors didn't have either B hepatitis or $\mathrm{C}$ hepatitis. Elzouki has found among the blood donors of Libya a prevalence of the antigen of the hepatitis $\mathrm{B}$ and anti-hepatitis $\mathrm{C}$ antibodies respectively of $2.2 \%$ and $1.3 \%$ [9]. Patients with immunosuppressive status with respect to the hepatitis $\mathrm{C}$ virus have been met [10].

Samples with bile pigments, the doorstep of $3.9 \mu \mathrm{mol} / \mathrm{L}$ corresponding to $(++)$ on the reactive bandages has held more cases, I mean $65.2 \%$ with Hepatitis B and $40 \%$ with HC hepatitis. At the $1.5 \mu \mathrm{mol} / \mathrm{L}$ doorstep and $7.8 \mu \mathrm{mol} / \mathrm{L}$, Hepatitis B has got respectively $8.7 \%$ and $26.1 \%$ of cases; and Heaptitis $C$ had $33.3 \%$ and $26.7 \%$ of cases. These adjustments had been compared to the doorstep of sensitiveness of stalks which is $0.5 \mathrm{mg} / \mathrm{dl}$.

In all, these results prove that the disease is discovered lately because other sensitive check up may detect the virus.

Regarding to the profile of checked up patients, we realized that many of 
Table 2. Results of bile pigments at the patients considered as HBV/HCV positive.

\begin{tabular}{cccc}
\hline & Bilurbinery & HBV positive & HCV positive \\
\hline \multirow{3}{*}{ Positive } & $+(1.5 \mu \mathrm{mol} / \mathrm{L})$ & $2(8.7 \%)$ & $5(33.3 \%)$ \\
& $++(3.9 \mu \mathrm{mol} / \mathrm{L})$ & $15(65.2 \%)$ & $6(40 \%)$ \\
& $+++(7.8 \mu \mathrm{mol} / \mathrm{L})$ & $6(26.1 \%)$ & $4(26.7 \%)$ \\
& Total & $23(100 \%)$ & $15(100 \%)$ \\
\hline
\end{tabular}

$\mathrm{X}^{2}=6.28 ; \mathrm{p}=0.043 ; \mathrm{ddl}=2$.

Table 3. Dispatching of hepatitis cases positive regard to the sex.

\begin{tabular}{ccccc}
\hline \multirow{2}{*}{ Sex } & \multicolumn{2}{c}{ HBV positive } & \multicolumn{2}{c}{ HCV positive } \\
\cline { 2 - 5 } & Size & $\%$ & Size & $\%$ \\
\hline Male & 20 & 86.94 & 11 & 73.3 \\
Female & 3 & 13.04 & 4 & 26.7 \\
Total & 23 & 100 & 15 & 100 \\
\hline
\end{tabular}

$\mathrm{X}^{2}=1.12 ; \mathrm{p}=0.289 ; \mathrm{OR}=2.4 ; \mathrm{CI}^{95 \%}=[0.46 ; 12.86]$.

Table 4. Dispatching of positive cases with regard to HBV tests according to the age.

\begin{tabular}{ccc}
\hline Age (in years) & HBV positive & HCV positive \\
\hline$\leq 25$ & $7(30.4 \%)$ & $4(26.6 \%)$ \\
$>25$ & $16(69.5 \%)$ & $11(73.3 \%)$ \\
Total & 23 & $15(100 \%)$ \\
\hline
\end{tabular}

$\mathrm{p}=0.8023 ; \mathrm{OR}=1.2 \mathrm{CI}^{95 \%}=[0.28 ; 5.12]$.

patients were male suffering hepatitis at least $86.94 \%$ with hepatitis B positive and $73.3 \%$ with hepatitis C positive. Women having $13.04 \%$ were less represented with hepatits B and 26.7\% Hepatitis also.

As far as the research was upon volunteers, we try to understand that several men agree to be donors than women in our surroundings. However, Habou Hadiza Akilou [5] has discovered that the degree (prevalence) of HCV antigene was higher at women than men (90.7\% against $71.87 \%)$.

Considering the Table 4, we have also detected that out of 23 cases known positive with bile pigments recognized in the urines of donors with hepatitis B positive, 7 donors I mean $30.4 \%$ were less aged or equal to 25 years old and 16 donors I mean $69.5 \%$ were more aged than 25 years old.

Concerning to HCV, 4 donors or $26.6 \%$ were less aged or equal to 25 years old and 11 donors or $73.3 \%$ were more aged than 25 years old. The age was also one of the conditions to be called universal donor. In this surrounding, we had examined only those patients who were 25 years old.

\section{Conclusion}

Our researches have confirmed that there was a hepatic disfunctioning after checking on different volunteer donors. A hyper bilurbine in the case of hepatitis 
has been discovered. A deep research via transaminases dosage or Y-GT on one too much representative sample should be interesting to evaluate a place of each virus in the destruction of the liver.

\title{
Authors' Contribution
}

All authors contributed in the different phases of the research.

\section{References}

[1] Lows, B. (2004) Human Virology. $2^{\text {th }}$ Edition, Masson, Paris.

[2] Marchal, G., Hoff, X., Pailler, J.L. and Perrot, M. Knowledge of Human Body. 2th Edition, Etudes Vivantes, Paris.

[3] National Committee for Clinical Laboratory Standard (1992) Routine Analysis and Collection Transportation and Preservation of Urine Specimens. Tentative Guideline, 12, 26.

[4] Ngo Sack, F., Noah Noah, D., Zouhaïratou, H., et al. (2013) Prevalence of HBs Antigen and Anti-HCV Antibodies in Homozygous Sickle Cell at Yaounde Central Hospital. The Pan African Medical Journal, 14, 40.

[5] Habou Akilou, H. (2009) Study of the Prevalences of ANTI-HCV and HBS Antigens Using Data from the Microbiology Laboratory and the Gastroenterology Department of Ibn Sina Hospital in Rabat. http://hdl.handle.net/

[6] Berthélémy, S. (2015) Liver Assessment. Pharmaceutical News, 54, 59-61.

[7] Delanghe, J. (2001) Examinations of the Urine. Vector, Garant.

[8] Maurey, C. (2005) Urinary Biological Semiology. http://www.em-consulte.com/es/article/174232

[9] Elzouki, A.N., Smeo, M.N., Sammud, M., Elahmer, O., Daw, M., Furarah, A., Abudher, A. and Mohamed, M.K. (2013) Prevalence of Hepatitis B and C Virus Infections and Associated Risk Factors in Libya: National Sero-Epidemiological Survey. The Eastern Mediterranean Health Journal, 19, 589-599. https://www.ncbi.nlm.nih.gov/pubmed

[10] Durand, F., Danic, B., Tardivel, R., Semana, G., Gouezec, H., Martinot, M., Marcellin, P. and Beauplet, A. (2000) Discovery of a Chronic Infection by HCV without Seroconversion in a Blood Donor in France during 28 Months. Clinical and Biological Transfusion, 7, 242-250.

\author{
Abbreviations Used \\ HBV: Hepatitis B virus; \\ HCV: Hepatitis C virus; \\ HB: hepatitis B; \\ HC: hepatitis C; \\ OR: Odds Ratio; \\ CI: confidence interval.
}

